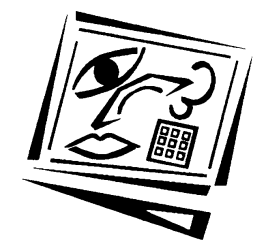

\title{
Online learning: Implications for effective learning for higher education in South Africa
}

\author{
Maylene Y Damoense \\ Monash University South Africa Campus
}

Over the last decade there has been an augmenting shift away from the conventional teaching and learning to modes where the Internet now plays a key role. E-learning is increasingly forming an integral part of course delivery and instruction, and is reshaping traditional learning world wide.

This paper outlines the shift from traditional learning to online learning practices. Then it discusses the use of technology, particularly the Internet, to support and enhance effective learning based on the principles of engagement theory. It considers relevant studies within the context of technology based learning, and highlights important experiences and findings. The paper indicates that technology based pedagogy and an effective online learning environment are crucial to support and enrich effective learning outcomes. The paper considers implications for South African higher education in the 21st century. Integrating the Internet as part of a curriculum is proposed, to instil our learners with lifelong skills.

\section{Introduction}

In recent years online education, particularly the adoption of the Internet, in academic teaching and learning has been growing rapidly. The global market for e-learning ${ }^{1}$ presently stands at an estimated US\$300 billion and is expected to grow to US\$365 billion by the year 2003 (Moe \& Blodgett, 2000). Within this market, e-learning in higher education is continuously expanding and changing due to rising enrolments globally.

It is estimated that 280,000 South African school and university learners were online at the end of 1999 and that this figure is likely to rise to 360,000 by the end of 2000 (NUA, 2000). Thus the local higher education online market is expected to grow substantially in this era of globalisation

${ }^{1}$ E-learning refers to any learning that utilises a network, such as the Internet, for delivery, interaction or facilitation (e-learners.com, 2001). Also used interchangeably with online education. 
and technological advancement, presenting major challenges for educators and learners. In particular, online teaching and learning changes the roles and skills that traditionally were required of educators. In addition, South Africa's higher education system is presently experiencing major transformation and restructuring that poses further challenges for educators and learners.

This paper examines how online learning, particularly employing Internet technologies, may encourage and support effective learning. More specifically, the paper argues that effective online learning utilising the Internet can best be attained by merging it with traditional face to face teaching and learning practices, with emphasis on sound technology based pedagogy incorporating the principles of engagement theory. 'Effective learning' refers broadly to the increased connectedness between effective learning processes (such as collaboration, interaction, participation, responsibility), and learning outcomes and objectives (higher order thinking, critical thinking and problem solving skills) (Watkins, et al, 1996; Pomorina, 2000). In reviewing the literature, evidence shows that by using the Internet in teaching, exciting opportunities are provided to both learners and teachers that facilitate collaborative, project based and authentic activities, which are otherwise not available through the traditional face to face mode of teaching.

Effective learning will determine effective learning outcomes, which in turn will build human capacity and contribute to the economic well-being of our learners and society as a whole. Furthermore, the skills and knowledge that will be acquired through use of the Internet may be advanced into the workplace. This is in line with one of the priorities indicated by the objectives of South Africa's National Plan for Higher Education: "To produce graduates with the skills and competencies required to participate in the modern world in the 21st century" (Ministry of Education, 2001:18). For South African graduates to become multiskilled and competitive in the modern workplace, our education institutions have to follow and adopt global education trends in technology and innovation.

\section{Research approach}

This paper is based upon theoretical research, and case studies. The method of investigation involved an examination of relevant theoretical and empirical perspectives regarding technology based education, particularly the adoption of the Internet as a learning tool at education institutions across a range of disciplines both at domestic and international educational institutions. The paper examines the shift from the traditional mode of learning in a face to face environment to online learning in the context of learning theories. On the basis of case studies, it considers 
evidence of learner effectiveness using the Internet and implications to enhance and support effective online learning. The paper also highlights implications and challenges for effective online learning for South African higher education learners in the 21st century. It is important to note that empirical evidence measuring the effectiveness of the traditional mode of learning compared to online learning is relatively limited (Bork, 2001; Taylor, 2002), especially in the context of engagement theory (Kearsley \& Shneiderman, 1999).

\section{Learning paradigms: A shift from traditional to technology based}

The theoretical literature examined provides numerous learning theories, which have shaped learning over the years. However, for purposes of this paper, the author will highlight four learning theories, namely, constructivism, problem based learning (PBL), experiential learning and engagement theory. Previously these theories have been modelled within a framework of traditional face to face instruction and learning. However, they are in part relevant to online learning, but with no or limited use of educational technology and innovation. Table 1 provides brief descriptions these learning theories, including the relatively new engagement theory of learning, which is applicable to learning in a technological environment. Importantly, it encompasses the principles of the first three theories outlined in Table 1.

Table 1: Learning Theories

\begin{tabular}{|l|l|}
\hline Learning theory & Description of theory \\
\hline $\begin{array}{l}\text { Constructivist } \\
\text { theory }\end{array}$ & $\begin{array}{l}\text { Learning by constructing new ideas and knowledge based } \\
\text { upon past and present experiences. Learning involves } \\
\text { cognitive and social processes (Bruner, 1990; Fardouly, 1998; } \\
\text { Wilson \& Lowry, 2000). }\end{array}$ \\
\hline $\begin{array}{l}\text { Experiential } \\
\text { learning }\end{array}$ & $\begin{array}{l}\text { Experiential learning involves practice and learning by doing. } \\
\text { Learners actively participate, are self initiated, and acquired } \\
\text { knowledge is applied and reflected upon (Kelly, 1997; Rogers, } \\
\text { 1994). }\end{array}$ \\
\hline $\begin{array}{l}\text { Problem based } \\
\text { learning } \\
\text { (PBL) }\end{array}$ & $\begin{array}{l}\text { With PBL, a problem is presented prior to students having } \\
\text { been taught the basic concepts. Students learn to be self } \\
\text { directed, motivated and independent, acquire problem solving } \\
\text { skills, and it promotes collaboration (Pomorina, 2001). }\end{array}$ \\
\hline $\begin{array}{l}\text { Engagement } \\
\text { theory }\end{array}$ & $\begin{array}{l}\text { Personally meaningful 'real' problems are presented to } \\
\text { learners. Involves increased levels of collaboration, } \\
\text { interactivity and participation. All individuals in a team are } \\
\text { engaged and responsible for their own learning experiences } \\
\text { (Jones, et. al. 1994; Kearsley \& Shneiderman 1999; Salmon, } \\
\text { 2001). }\end{array}$ \\
\hline
\end{tabular}


Traditional teaching and learning practices, based on the 'transmission model' of teaching delivery and instruction, involved limited participation and active learning, with students taking little responsibility for their own learning experiences (Coventry, 1997; Kennedy, 1998; Poulter, 2000). Best practice acknowledges that traditional face to face lectures are "relatively ineffective in terms of providing an opportunity for learning" (Poulter, 2000:1) and that it is associated with a number of restrictions (Ashton \& Zalzala, 2000; Bork, 2001; Govender et al, 2001) that may prohibit effective learning from taking place. Although traditional face to face offerings can result in some learning, complementing it with the Internet is more likely to result in significantly more effective learning.

Engagement theory ${ }^{2}$ provides a theoretical framework for learning in a technology based environment that is likely to contribute significantly to effective learning processes and experiences. The main themes of this theory include construction, collaboration, interactivity, problem solving and authenticity. The principles of engagement theory especially relevant for technology based teaching and learning include three components, (i) establishing learner-learner collaborative teams, (ii) encompassing a project based learning approach, and (iii) designing an authentic learning environment and authentic tasks (Agostinho, et. al., 1997; Kearsley \& Shneiderman, 1999; Salmon, 2001). Under the engagement theory of learning, the method of instruction is interactive (instruction actively engages the learner and promotes collaboration) and generative (instruction encourage learners to construct and produce meaningful conceptions, solve problems, think critically, develop higher order thinking skills, make decisions, apply knowledge, etc.) (Jones et al, 1994).

In terms of the first principle, greater collaboration and interaction between learners is essential pedagogy for effective learning, which tends to be more conducive in an online learning environment. With greater collaboration, opportunities exist for team members to express their views and respond to each other's ideas, thus allowing them to construct new ideas and thoughts (constructivism). The use of electronic mail has proved to be the most effective and frequently employed collaborative tool in online education (Agostinho, et al, 1997; Kearsley \& Shneiderman, 1999; Singh \& Erwin, 2001). Others include HTML documents, online discussion forums and seminars, live chats, etc, that facilitate interactivity and participation, for instance, multiple dialogues that cannot be implemented effectively in a traditional face to face class setting. Posting group or team projects on the web allows learners to put more effort into it, especially if

${ }^{2}$ The emergence of engagement theory was formulated by Shneiderman (1994) and is based on his teaching experiences in electronic and distance education environments. 
they are aware of the wider audience that might view their work (Agostinho, et. al., 1997; Kennedy, 1998; Clougherty, 2001). In posting their [learners] final projects on the Web that they themselves have created, active learning is promoted through collaborative efforts (Fetterman, 1997; Kearsely \& Shneiderman, 1999).

Project oriented learning, the second principle of engagement theory, essentially stems from the theory of problem based learning (PBL). The instructional strategy includes a project based task or exercise, which provides a vehicle for learning new information in a context that is meaningful, exposing learners to 'real' problem oriented cases relevant to their learning outcomes. Project based learning can be enhanced and achieved with greater efficiency if implemented with web based resources.

In terms of the third principle, that is, providing an authentic focus to tasks, the authentic setting for learning refers to engaging the learner with a real world problem and challenge, especially relating it to the interests of learners (Daley, et al, 2001; Kearsely \& Shneiderman, 1999). Authentic tasks, for example developing a business report, journal or newspaper article, or participating in an interactive stock market game, simulations, etc, have been noted to increase the level of interests of learners, and hence improve also their motivation levels. The traditional 'textbook' problem is thus not consistent with an authentic activity. Alcock \& McFarlane (2001:4) maintain, "If students are to benefit from the subjects that they are studying, it is important that they have an interest in the end results of the tasks they are required to perform". Thus an authentic learning environment will promote connectedness to the real world because projects are based on real world issues and challenges, and are related to learners' interests. Although the framework proposed by engagement theory broadly relates to technology based learning, it can more specifically support Internet learning.

Collectively, collaboration, project based and authentic learning, which Salmon (2001) terms e-tivities ${ }^{3}$, can be supported effectively by using the Internet in conjunction with traditional learning practices (Agostinho et al, 1997; Kennedy, 1998). Dialogue and collaboration in a traditional face to face environment are relatively limited. However, in a technology based environment where the web is used in learning for an authentic project or task that is practical and applied, effective collaboration and communication, and greater interaction are likely to result. Within this framework, the Internet can assist learners to build meaningful understandings of difficult content material, apply critical and creative

${ }^{3}$ E-tivities refers to the principles of engagement theory; namely, collaborative, project based and authentic learning activities. 
thinking and solve problems (Slay, 1997). Reflective interaction is also animated and supported (Agostinho, et. al., 1997).

The web offers many possible resources that can enhance and support traditional teaching instruction and delivery, and learning. It provides access to information sources, encourages meaningful interactions with subject specific content and enhances collaboration among individual learners (Greeno et al, 1998); including collaboration between the instructor and learners (Tan \& Wong, 1996). Thus the Internet facilitates collaboration, interactivity, and project oriented learning, and provides an authentic environment for learning (Kennedy, 1998; Kearsley and Shneiderman, 1999; Deacon et al, 2000). Very importantly, it supports a variety of learning styles and student backgrounds (Tan \& Wong, 1996; Slay, 1997; de Villiers, 2001; Ashton \& Zalzala, 2000), and advances the equalisation of learners (Kennedy, 1998). An Internet based learning environment enables users to exercise more control over their learning experiences (Brack, 1996; Kearsely \& Shneiderman 1999). This is especially true for students with different learning styles, since the Internet can be used in an asynchronous environment allowing them to work at their own pace at any suitable location.

There exist a variety of web resources that can be used in teaching and learning. However, they do not necessarily lead to favourable learning outcomes. In the absence of the creation or design of an effective online learning environment this cannot be achieved. The Internet can be used to create and support such a learning environment that will enhance learning processes, encompassing activities involving interactivity and flexibility, motivation and confidence, collaboration, construction of knowledge and active learning, that are noted to have delivered quality e-learning experiences (Tan \& Wong, 1996; Agostinho, et. al., 1997; Shneiderman \& Kearsley, 1999; Salmon, 2001).

A perceived disadvantage of using the web is that the number of links and information available might overwhelm some learners, hence confusing and discouraging them. Traditional teaching modes include the reliance on print materials (Alcock \& McFarlane, 2001), particularly the traditional textbook, since "It organises an enormous amount of information in a socially acceptable pattern" (Rockman, 1999), which is not provided by the web. On the other hand, increased access to rapidly updated information, interactivity and collaboration, are all opportunities provided when using the Internet in learning. Internet tools such as WebQuest and WebCT are increasingly being employed with teaching to facilitate active learning. Web based course materials are now being designed for use as a supplement to textbook materials used in traditional teaching and learning environments (Axelson \& Hardy, 1999). 
The following section is based on findings from relevant case studies conducted. These experiences will provide us with some lessons regarding the effectiveness of e-learning, when complemented with traditional teaching activities, encompassing e-tivities, the components of engagement theory.

\section{The Internet and learning: Case studies and experiences}

Several studies indicate that using educational technology, including the Internet, to complement and enhance traditional instruction and learning will lead to effective learning outcomes (Summary \& Summary, 1998; Ashton \& Zalzala, 2000; de Villiers, 2001; Hogarth, 2001). It is important to note that the case studies the author considered have not been explicitly conducted within the framework of engagement theory of learning. The reason for this is that it is a relatively new learning theory. However, the studies consulted tend to support the claim that effective learning outcomes are best attained when using the Internet together with traditional instruction and delivery, that incorporates the principles of engagement theory resulting in effective learning processes, including improved attitudes, participation, interactivity, motivation, confidence, interest, etc.

The literature researched indicates that online education encompasses a relatively high degree of student interaction and participation when compared to traditional face to face learning. Many authors have found that students who took a course through an online or technology medium acknowledged that their participation levels increased and were far greater than in a course they took that was offered purely by means of traditional face to face instruction. A study by Daley et al $(2001)^{4}$, established that learners' attitudes and perceptions were largely determined by their level of participation in an e-learning environment, and hence had a positive impact on their learning experiences. In this study, each student in a group presented a problematic case from their respective practices as adult educators, and facilitated the discussion of their respective cases for one week. When a student was not leading the discussion, that student participated as a group member in the discussion of other students' cases. Each group consulted web resources and made database inquiries to explore and challenge students' cases, and share experiences through dialogue.

Furthermore, if the attitudes and perceptions of learners were positive, they were able to acquire knowledge that is not only subject specific in content, but their learning experiences were associated with increased cognitive skills such as problem solving, decision making, analytical,

\footnotetext{
${ }^{4} 46$ students and 5 facilitators were divided into 9 groups for the study.
} 
critical thinking, and others. These learning processes tend to foster effective learning outcomes because there exists a positive motivational effect on learners that is associated with the use of technology in education (Valdez, et. al., 2001; de Villiers, 2001). Thus there is a strong relation between positive attitudes and perceptions, motivation, confidence and participation when learners interact and collaborate in a technology based environment. In the context of engagement theory, interaction and participation are closely connected to collaboration. Further, project based and authentic learning was encouraged and led to successful learning experiences.

Summary \& Summary $(1998)^{5}$ at Southeast Missouri State University, Department of Economics conducted a study to determine the impact of web based instruction upon student attitudes, performance and more specifically interest in the subject (first year level economics). Web based instructional resources included online syllabi, online tutorials, links to course related material on the web, and bulletin boards. The study concluded that using Internet resources synchronously did indeed contribute to greater interest in the subject because their attitudes towards economics improved. Eighty per cent of the respondents found that their learning experiences were indeed enhanced (Summary \& Summary, 1998:1-8). The results revealed that integrating WebCT tools that facilitate collaboration and project based learning, and provide an external or authentic environment, enhanced the learning experiences of participants.

One study very relevant for engagement theory of technology based learning, particularly within the context of project orientated learning, is that conducted by Deacon et al (2001:1-8). A pilot course was developed in 1999 at the University of Cape Town, South Africa, for students enrolled in a BCom degree. The course adopted a project based learning framework to address problems due to most South African higher education learners entering the university system with a limited knowledge of real world economic issues. The pilot study tutorial was based on the 'South African gold mining industry'. The materials developed for the course comprised an interactive Microsoft Excel tutorial, a virtual share trading game, and an online discussion forum. By means of Excel charts, students were able to use their mouse to find the gold price at a specified date. Gold mining company data and production data were made available from web sites linked to the Excel worksheet. This enabled students to investigate how the profitability of gold mining companies could change in reaction to

\footnotetext{
${ }^{5}$ The survey consisted of a pre-survey and a post-survey for 'users' and 'nonusers'. Responses include pre-survey users (269) and post-survey users (169) and pre-survey for non-users (307) and post-survey for non-users (239) (Summary \& Summary, 1998). Numbers in brackets represent student numbers.
} 
fluctuations in the Rand and Dollar exchange rates or the gold price (which students could manipulate).

Next, students were given R100,000 of virtual money to invest in shares of the researched mining companies for use in a share trading game (authenticity). Lastly, students were required to prepare a relevant newspaper article, using the discussion forum for this task, thus creating an environment for them to articulate their views and respond to others. The virtual share trading activity and the online discussion forum were rated highly by students, primarily because their levels of interest rose with the first activity, which represents a real world experience, and they became increasingly motivated during the latter activity, because greater collaboration and participation were required in the discussion forum.

Research further indicates that using the Internet provides flexibility, especially in enhancing and supporting traditional teaching practices so as to cater for learners with varied learning styles and abilities. Computer based learning facilitates interactivity and allows the instructor to modify and customise content to meet the needs of individuals (Park, 1996; Valdez et al, 2001), especially for students with different backgrounds, learning styles and disabilities (de Villiers, 2001). For example, employing multimedia illustrations, such as visual images and simulations, in delivery and instruction better stimulates some learners (Ashton \& Zalzala, 2000), thus emphasising the 'authentic learning' component of engagement theory.

Numerous studies show that educators lack the required skills and knowledge for effective Internet course instruction and delivery (Cronje, 2001; Singh \& Erwin, 2001; Valdez et al, 2000). Lecturers who aspire to increasingly employ the Internet as a teaching and learning tool "usually require support and assistance" (Bagdon \& Gross, 1997:1), especially when it comes to the technical aspects of web based course design (Alcock \& McFarlane, 2001). In cases where instructors are not adequately experienced in the technical aspects of web based course design, they should work closely with information technology personnel. This is particularly important to ensure that the instructor can maintain his or her focus on aspects relating to pedagogy and learning strategies, which are crucial for the succeeding in the context of engagement theory.

A study by Cronje $(2001: 8)^{6}$ affirmed that “... lack of knowledge about technology" and "too little knowledge of WebCT to use it optimally" are major concerns for lecturers using WebCT in their teaching programs.

${ }^{6}$ Study conducted at Rand Afrikaans University (RAU), South Africa. At RAU 38 lecturers used WebCT in over 50 courses. The sample was 16 responses. 
Internet based sessions need trained synchronous instructors to assist and give guidance to learners on a continuing basis (OLT, 2001).

The afore-mentioned studies reveal that Internet based learning within the framework of the principles of engagement theory will lead to enhanced, more effective learning outcomes. Hence, we can deduce important implications for effective online learning emphasising collaborative, projectbased and authentic learning.

\section{Implications for effective online learning}

This section of the paper discusses four aspects of effective online learning that are critical to ensure effective learning outcomes. They include (i) creating an effective online learning environment to support effective learning outcomes, (ii) issues relating to pedagogy of technology emphasising collaborative, project-based and authentic learning activities, (iii) assessing effective online learning outcomes, and (iv) integrating the Internet into a curriculum. As already referred to elsewhere, the theory of engagement is a relatively new theory, however the author has attempted to incorporate the principles of engagement theory to provide important implications for effective online learning.

\section{i. Creating an effective online environment}

Designing an effective online learning environment is essential and must be well structured to efficiently and effectively engage learners. It provides opportunities for learners that will support the learning process effectively. For learning to be effective, it must occur within a context that is meaningful to the learner and in which collaboration can be facilitated (Jones et al, 1994; Aghostino et al, 1997). Teaching online is more demanding than traditional face to face teaching, especially in terms of the time required online for searching and organising web materials (Agostinho et al, 1997; Hogarth, 2000), and for planning and designing web based activities for problem based projects with an authentic focus (Deacon, et. al., 2000).

Figure 1 outlines a proposed model for the lifelong learners' environment, showing two learning environments, traditional learners' (A in Figure 1) and online learners' environments (B in Figure 1).

The environment of the traditional learner (A in Figure 1) indicates that the lecturer or instructor transfers knowledge to the learner through the medium of printed materials, particularly textbooks and lecture notes. In this type of environment, there is no technology usage and little or sometimes no participation and collaboration. On the other hand, the online environment (B in Figure 1) promotes project based and authentic 
learning, and provides opportunities for interactivity, collaboration, motivation and confidence, and engaged learning.

Figure 1. Lifelong learners' environment

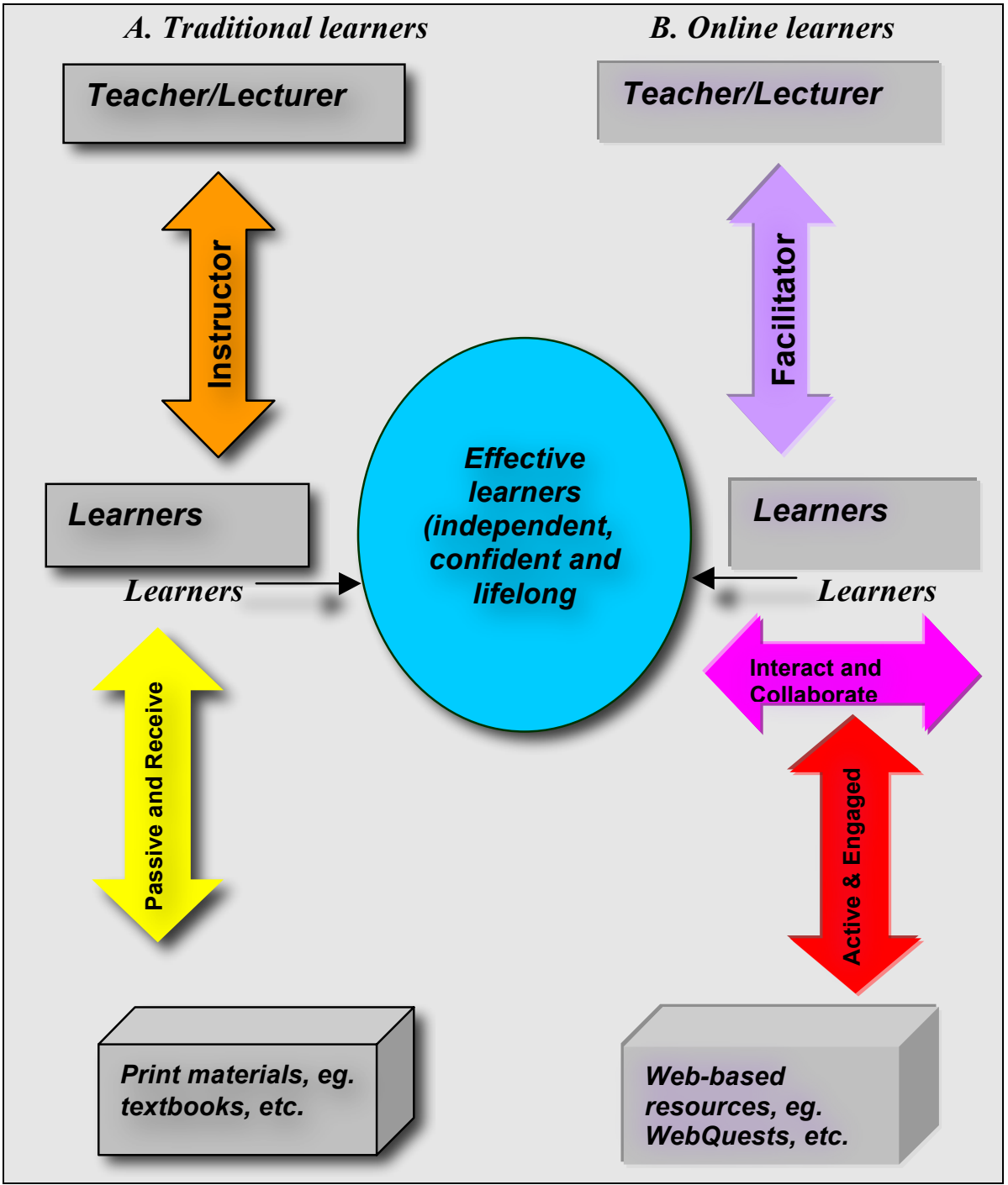

Source: Author

Figure 1 further indicates that by merging the learning environments, learning is likely to be reinforced and enriched with the support strategies 
provided by a technology enhanced environment (illustrated by the oval shaped structure in Figure 1). Hence, effective learning will result since the learners acquire spheres of knowledge that will enable them to become lifelong learners.

One effective e-learning environment is the implementation of WebQuest activities that are conducted in a traditional instructional setting. The WebQuest model was developed by Dodge and March in the beginning of 1995. Dodge (1997:1) defines a WebQuest activity as an "inquiry oriented activity in which some or all of the information that learners interact with comes from resources on the Internet..." Student motivation is enhanced, active learning is promoted, collaborative effort takes place, higher order thinking and problem solving skills are developed and performance based outcomes are attained (March, 1997; March, 1998; Warters, 2000; Wood, 2001).

The format of a typical WebQuest program commences with introductory background information about the task, the task itself (group task), description of the process to follow, available online resources and printed materials. Guidance is provided and a conclusion linked to learning objectives (Dodge, 1997; March, 1997; March, 1998). Each individual in a team adopts a particular role and responsibility within the broader context of the task. Importantly, WebQuest incorporates the features referred to under engagement theory of learning and supports technology based pedagogy in that the learning task is authentic, active learning is meaningcentred on real world issues and it supports higher order thinking skills.

Another e-learning environment is WebCT This is an integrated learning environment, which extends the boundaries of the traditional classroom. WebCT's e-learning hub provides a range of web resources, including online course materials and communication tools that facilitate online active learning and collaboration. Furthermore, it provides the flexibility for the ongoing inclusion of updated materials (Ashton \& Zalzala, 2000; Alcock \& McFarlane, 2001) and greater access to information that is not readily available in a non-technological teaching environment.

Hence, an effective online learning environment can facilitate pedagogy relating to technology (collaboration, project-based and authenticity) that is essential for determining effective learning outcomes. Furthermore, merging the two learning environments is important to create a viable environment to support and enhance effective learning. In other words, an e-learning environment, represented by B (in Figure 1), complements and supports the traditional dimensions of learning denoted by A (in Figure 1), to achieve greater efficiency and effectiveness in learning (Tong \& Wong, 1996; Deacon, 2000). 


\section{ii. Issues of pedagogy and technology}

It is a widely held view that "learning effectiveness is a function of effective pedagogical practices" (Joy et al, 2000:6). Pedagogical practices under e-learning should incorporate activities that promote and facilitate constructivist, interactive, and collaborative learning. In other words, traditional pedagogy needs to be adapted to pedagogy relating to a technology based learning environment, which emphasises the principles of engagement theory. Crucially, "Technology is an important resource for any student but it is not valuable in a vacuum" (Fetterman, 1997:39). There is no doubt that teachers must take greater responsibility (Agostinho et al, 1997; Hart, 2001) developing online course materials (Agostinho et al, 1997; Hogarth, 2001) to ensure sound technological pedagogy. When combining pedagogical practices emphasising the principles of engagement with the Internet, in a face to face classroom setting (Tan \& Wong, 1996; Agostinho et al, 1997; Schrum, 2000), learning can be reinforced and enriched.

\section{iii. Assessing effective online learning outcomes}

According to the studies that have been consulted, effective learning has indeed been supported and animated by adopting the Internet as a learning tool. Evaluation of effective online learning includes feedback from participants [learners] in pilot studies, questionnaires and surveys (Summary \& Summary, 1998; Fong, 1999; Alcock \& McFarlane, 2001; de Villiers, 2001), tests (Kearsley \& Shneiderman, 1999), web based and traditional assessments, such as online seminars, projects and reports (Fetterman, 1997; March, 1998), presentations (Orsini-Jones, 2001), student evaluations (Summary \& Summary, 1998; Hogarth, 2001), participant observations (de Villiers, 2001; Daley et al, 2001) and instructor or lecturer feedback (Shneiderman, 1994). Measuring online learning effectiveness is subject to certain flaws, such as instrument design flaws, lack of adequate controls, sample size, short investigation periods, etc. More advanced empirical models will be required in the future to determine learner effectiveness, and whether the principles of engagement theory if adopted indeed yield the promised learning outcomes.

\section{iv. Integrating the Internet as part of a curriculum}

Lecturers or instructors should consider adapting existing curricula or possibly designing "new" ones that will complement Internet based projects and learning (Tan \& Wong, 1996; Fong, 1999; Cronje, 2001; March, 1998). By integrating the Internet as part of a curriculum, it is likely to significantly enhance and support effective, lifelong learning, as it provides a flexible approach to teaching and learning. WebQuest programs and WebCT applications in teaching and online learning are 
particularly useful and are already employed at many educational institutions. Adapting it to a current curriculum with emphasis on engagement theory of learning, employing e-tivities, represents a valuable approach to learning effectively online.

\section{Implications for effective online learning for South African higher education learners}

Higher education in South Africa has been subject to major transformation since the mid-1990s. Rising enrolments of historically 'black' disadvantaged students in historically 'white' higher education institutions are prevalent. This implies that a large proportion of learners in higher education institutions are under-prepared for tertiary education, and are experiencing a range of problems associated with learning. In other words, the majority of learners do not fit the elusive 'model academic learner' (Dison \& Pinto, 2000).

This has led to academic programs developed and implemented within the boundaries of the recently established South African Qualifications Authority (SAQA) and National Qualifications Framework (NQF), which emphasise outcomes based education (OBE) for higher education learners. In the South African context, outcomes based learning implies learning that exhibit the attainment of outcomes, including the engagement of learners in the learning process. In addition, educational technology is becoming increasingly important in teaching and learning practices in many South African higher education institutions.

The author attempts to link outcomes based learning in higher education to engagement theory of learning. Breier (2001) identifies teaching strategies for higher education in South Africa that are crucial for lifelong learning and a restructured curriculum. These include among others; “...use of peer assisted and self directed learning, experiential and real world learning, they make use of problem based learning..." (Breier, 2001:14-15), which implies the principles of engagement theory. Further, when considering outcomes based learning in relation to the principles of engagement theory within the context of an e-learning environment, we can expect effective learning outcomes.

Thus, in the South African higher education context sound technology based pedagogy (collaboration, project-based and authentic), the adoption of the Internet as a teaching tool merged with traditional teaching and learning practices must be complementary to obtain effective learning outcomes and maintain the quality of subject content.

The challenge to instructors at higher education institutions is to seek appropriate mechanisms to develop an online learning environment that 
will facilitate motivation, confidence, participation, problem solving, analytical, and high level thinking skills. As already stated, technology based learning offers many learning opportunities that can provide such mechanisms and resources to spur active and outcomes based learning. The Internet provides flexibility and interactivity in learning, which can be particularly useful for the backgrounds and learning styles of South African learners.

In South Africa, there are large numbers of remote learners located away from the hub of higher education institutions. The use of computers in education should increasingly be viewed as an effective communication tool with vast opportunities for addressing the needs of these learners, since geographical location and time do not matter in an asynchronous elearning environment. However, infrastructure and access in remote regions are major obstacles, difficult for the Government of South Africa, as socio-economic problems, such as the current HIV/AIDS pandemic ${ }^{7}$, rising poverty and unemployment ${ }^{8}$ impose great demands upon our nation's financial resources.

Educators at South African institutions are not adequately equipped with the necessary technology skills, particularly in using the Internet as a tool in their teaching. Adopting it will enable them to extend the limitations of the boundaries associated with traditional classroom environments, and provide them with flexibility and opportunities to further advance their teaching strategies to meet the needs of our diverse learners. Hence, professional staff development and training in online education is crucial.

Finally, the author proposes that integrating the Internet into a curriculum will prepare learners for the challenges that will accompany the rapidly changing technological environment. It is important that restructured curricula incorporating the Internet with pedagogy relating to the principles of engagement theory be developed and implemented within the context of South Africa's National Qualifications Framework (NQF). Integrating the Internet into a curriculum will provide lifelong learning opportunities for personal and professional development of our learners.

\section{Conclusion}

The key to effective online learning is to increasingly engage learners. As the quality, sophistication and speed of access to web resources continue to improve, greater benefits are likely to accrue in adopting the Internet as

\footnotetext{
${ }^{7}$ It is estimated that 4.2 million South Africans are HIV positive (Aids Foundation of South Africa, 2000).

${ }^{8}$ According to Statistics South Africa, unemployment rose from 36.3 per cent in 1999 to 37.3 per cent in 2000 (afrol.com News, 2001).
} 
a learning tool in the future. This paper has indicated that using the Internet to learn, together with traditional face to face instruction, including sound technology based pedagogy emphasising the principles of engagement theory of learning, is likely to yield effective learning outcomes. Integrating the Internet into a curriculum, whether adapting an existing one or designing a new one, is likely to have a significant, positive impact on learning outcomes.

In South Africa, e-learning is in its infancy and the extent to which the Internet is used to foster learning is limited. Empirical findings are questionable. As more institutions are likely to employ the Internet in teaching and learning, further research will be required to investigate the effectiveness of using it to complement traditional on campus courses in South Africa.

Further investigations should include (i) determining the financial implications for integrating the Internet as part of a curriculum and the provision of ongoing professional development and training for staff, (ii) developing an empirical model to determine the effectiveness of learning by employing the Internet as a support tool to educational pedagogy, particularly for learners with different backgrounds, capabilities and learning styles, and (iii) designing local web based programs based on the principles of engagement theory; collaborative, project based and authentic learning.

\section{References}

AIDS Foundation of South Africa (2001). Aids in South Africa. [viewed 11 Dec 2001, verified 26 Jan 2003] http: / / www.aids.org.za/aids_in_south_africa.htm

Afrol.Com News (2001). Unions alarmed over rising SA unemployment. South Africa, 28 March. [viewed 11 Dec 2001, verified 26 Jan 2003] http:/ / www.afrol.com/News2001/sa016_unemployment.htm

Agostinho, S., Lefoe, G., \& Hedberg, J. (1997). Online collaboration for learning: A case study of a post graduate university course. Proceedings of the Third Australian World Wide Web Conference, 5-9 July, Southern Cross University, Australia. [verified 26 Jan 2003] http:/ / ausweb.scu.edu.au/aw97/ papers/agostinh/index.htm

Alcock, C. \& McFarlane, P. (2001). E-Learning: Moving from the traditional learning world to the e-learning world. Poster Session at the 23rd Annual Conference of the Pacific Telecommunications Council, Honolulu, Hawaii, 16 January. [viewed 22 Oct 2001] http: / / www.ptc.org/PTC2001/poster_sessions/tuesday/t2/ [restricted access 26 Jan 2002, see http:/ / www.ptc.org/library/proceedings/index.html]

Amos, T. L. (1998). Teaching and learning the discipline of marketing for success in a changing higher education context. Proceedings of the 1998 International Marketing Management (IMM) Marketing Educators Conference. Graduate School of Business, University of Cape Town, South Africa. 30 April, pp 6-26. 
Ashton, H. \& Zalzala, A. (2000). Enhancing traditional learning: The use of multimedia material on the Internet. Paper Presented at the 8th Annual Conference on Teaching of Computing, Edinburgh. [viewed 15 Oct 2001, verified 26 Jan 2003] http: / / www.ics.ltsn.ac.uk/pub/ conf2000/Papers/ashton.htm

Axelson, M. \& Hardy, L. (1999). Learning online: As web-based curriculum grows, are textbooks obsolete? Electronic-school.com, June 1999. [viewed 11 Dec 2001, verified 26 Jan 2003] http: / / www.electronic-school.com/199906/0699f1.html

Bagdon, K. \& Goss, H. (1997). Teaching and learning on the Internet: Developing a resource for academic support. Poster presentation at the Third Australian World Wide Web Conference, Southern Cross University, Australia, 5-9 July. [verified 26 Jan, 2002] http:/ / ausweb.scu.edu.au/aw97 / papers / goss / index.htm

Bork, A. (2001). What is needed for effective learning on the Internet? Educational Technology \& Society, 4(3), 139-144. [verified 26 Jan 2003] http:/ / ifets.massey.ac.nz/periodical/vol_3_2001/bork.html

Brack, C. (1996). Linking the data to develop knowledge: A neglected part of developing web-based university resource. Paper presented at Ausweb96, Gold Coast, Australia, July 1996. [verified 26 Jan 2003] http:/ / ausweb.scu.edu.au/aw96/educn/brack/index.htm

Breier, M. (2001). Higher education curriculum development: The international and local debates. In M. Breier (Ed), Curriculum Restructuring in Higher Education in Post-apartheid South Africa. Education Policy Unit, University of the Western Cape, Cape Town.

Bruner, J. (1990). Constructivist Theory. Explorations in Learning and Instruction: The Theory Into Practice (TIP) Database. [viewed 20 Nov 2001, verified 26 Jan 2003] http:/ / tip.psychology.org/bruner.html

Clougherty, R.J. Jr (2001). WebCT as the Literature Classroom: A Tool, a Subject, and a Model. Tennessee Technological University, Cookeville, Tennessee, USA.

Coventry, L. (1997). Video conferencing in higher education. Institute of ComputerBased Learning, Heriot-Watt University, Edinburgh. [viewed 14 Nov 2001] http:/ / www.man.ac.uk/MVC/SIMA/video3/two1.html [verified 26 Jan 2003 at http: / / www.agocg.ac.uk/reports/mmedia/video3/contents.htm]

Cronje, M. (2001). Experiences of lecturers using WebCT from a technology adoption perspective. Paper presented at the 3rd Annual Conference on World Wide Web Applications, Rand Afrikaans University, South Africa, 5-7 Sep.

Daley, B. J., Watkins, K., Williams, S. W., Courtenay, B., Davis, M., \& Dymock, D. (2001). Exploring in a technology-enhanced environment. Educational Technology E Society, 4(3), 126-138. [verified 26 Jan 2003 at http: / / ifets.massey.ac.nz/periodical/vol_3_2001/daley.html]

Deacon, A., Paxton, M. \& Carr, T. (2000). Creating a project-based learning environment for commerce courses by customising an Office suite. Proceedings, Conference on Information Technology in Tertiary Education (CITTE), University of Port Elizabeth, South Africa, March. http:/ / www.upe.ac.za/ citte2000/ [viewed 5 Dec 2001, verified 26 Jan 2003 at http: / / www.upe.ac.za/ citte2000/docs/adeacon.doc] 
De Villiers, G. (2001). An evaluation of asynchronous web-based learning technologies. Paper presented at the 3rd Annual Conference on World Wide Web Applications, Rand Afrikaans University, South Africa, 5-7 Sep.

Dison, L. \& Pinto, D. (2000). Example of curriculum development under the South African NFQ. In S. Makoni (Ed), Improving Teaching and Learning in Higher Education, A Handbook for Southern Africa. Witwatersrand University Press, South Africa.

Dodge, B. (1997). Some thoughts about WebQuests. Department of Educational Technology, San Diego State University. Latest update 5 May 1997. [viewed 26 Nov 2001, verified 26 Jan 2003] http:/ / edweb.sdsu.edu/courses/edtec596/about_webquests.html

E-Learners.com (2001). e-Learning Glossary. [viewed 8 November 2001 http: / / www.elearners.com/elearning/glossary.htm [verified 26 Jan 2003 at http: / / www.elearners.com/services/faq/glossary.asp]

Fardouly, N. (1998). Learner-Centred Teaching Strategies. Principles of Instructional Design and Adult Learning. The University of New South Wales, Faculty of the Built Environment, Sydney, Australia. Latest update 23 Dec 1998. [viewed 11 May 2001, not found 26 Jan 2003] http: / / www.fbe.unsw.edu.au/learning/instructionaldesign/strategies.htm

Fetterman, D. M. (1997). Learning curve: A compelling class seen through the eyes of professor and student. Stanford Today, July / August, pp 38-39.

Fong, S. C. C. (1999). Integration of WebCT into an accounting module: Studies of Hong Kong sub-degree students. Paper Presented at the CTI Accounting Finance \& Management Conference.

Greeno, J. G. \& the Middle School Mathematics Through Applications Projects Group (1998). The situativity of knowing, learning and research. American Psychologist, 53 (1) pp 5-26.

Govender, A., Heukelman, D., Khalili, P., Pete, M. \& Fregona, C. (2001). Can a virtual classroom address the problems associated with a large class of learners with diverse backgrounds? Paper presented at the 3rd Annual Conference on World Wide Web Applications, Rand Afrikaans University, South Africa, 5-7 Sep.

Hart, G. (2001). Some Perspectives on Establishing Online Learning Communities. Ultralab and Anglia Business School, Anglia Polytechnic University, Essex, UK.

Hogarth, S. (2001). The use of web pages and WebCT to preserve small-group work in seminars. Department of Educational Studies, University of York. Latest update 24 Sep 2001. [viewed 3 Dec 2001, verified 26 Jan 2003] http: / / cti-psy.york.ac.uk/aster/resources / case_studies/reports/yk_07/yk_07.html

Jones, B. F., Valdez, G., Nowakowski, J. \& Rasmussen, C. (1994). Learning Indicators: Designing Learning and Technology for Educational Reform. North Central Regional Educational Laboratory (NCREL) [viewed 20 Nov 2001, verified 26 Jan 2003]

http:/ / www.ncrel.org/sdrs/areas/issues/ content/cntareas/math/ma2lindi.htm 
Joy, E. H. II \& Garcia, F. E. (2000). Measuring learning effectiveness: A new look at no-significant-difference findings. Journal of Asynchronous Learning Networks, 4(1, June), 1-7. [verified 26 Jan 2003] http: / / www.aln.org/alnweb/journal/Vol4_issue1/joygarcia.htm

Kennedy, C. (1998). Online education: How does it benefit students. The Advocate, December. [viewed 31 Oct 2001, verified 26 Jan 2003]

http: / / smccd.net/ accounts / kennedyc/ rsch/advocate-dec.htm

Kearsley, G. (1998). Online education: New paradigms for learning and teaching. [viewed 29 Oct 2001, verified 26 Jan 2003] http:/ / home.sprynet.com/ gkearsley/allen.htm

Kearsley, G. \& Shneiderman, B. (1999). Engagement theory: A framework for technology-based teaching and learning. [viewed 16 Oct 2001, verified 26 Jan 2003] http:/ / home.sprynet.com/ gkearsley / engage.htm

Kelly, C. (1997). David Kolb, the theory of experiential learning and ESL. The Internet TESL Journal, III, 9 September, pp 1-6. [viewed 20 Nov 2001] http:/ / www.aitech.ac.jp/ iteslj/Kelly-Experiential/ [verified 26 Jan 2003 at http: / /iteslj.org/Articles/Kelly-Experiential/]

March, T. (1998). WebQuests for learning: Why WebQuests? An introduction. ozline.com, April. Latest update Sep 2001. [viewed 28 Nov 2001, verified 28 Jan 2003] http:/ / www.ozline.com/webquests/intro.html

March, T. (1997). Working the web for education: Theory and practice on integrating the web for learning. ozline.com, July/August. Latest update Sep 2001. [viewed 5 Nov 2001, verified 28 Jan 2003] http: / / www.ozline.com/learning/theory.html

Ministry of Education (2001). National Plan for Higher Education in South Africa. Pretoria, South Africa, February.

Moe, M. \& Blodget, H. (2000). The Knowledge Web. Merryll Lynch \& Co, Global Securities Research \& Economics Group, Global Fundamental Equity Research Department, p 189.

Ngubane B. S. (2001). Science and Technology for Sustainable Development in Africa. UNESCO Seminar, 8 November, France. Sunday Times, 11 Nov, p 22.

NUA (2000). Internet growth slowing in South Africa. Acuity Media Africa. NUA Internet Surveys, 24 May. [viewed 25 Oct 2001]

http: / / www.nua.ie/ surveys / ?f=VS\&art_... =true [verified 28 Jan 2003 at http: / / www.nua.ie / surveys / index.cgi? $\overline{\mathrm{f}}=$ VS\&art_id=905355799\&rel=true]

OLT (1999). Web-based ESL learning: An assessment of the Networked English Language Learning Project. Office of Learning Technologies, Human Resources Development Canada. [viewed 12 Nov 2001] http: / / www.olt-bta.hrdcdrhc.gc.ca/publicat/79071exesum_e.html [not found 28 Jan 2003 at http:/ / oltbta.hrdc-drhc.gc.ca/] 
Orsini-Jones, M. (2001). Web enhanced language learning (WELL) case studies: Completed case studies. Coventry University. [viewed 3 Dec 2001, not found 28 Jan 2003] http:/ / www.well.ac.uk/ casestud/orsini.htm

Park, O. (1996). Adaptive instructional systems, In D. H. Jonassen (Ed), Handbook of Research for Educational Communications and Technology. New York: Simon and Schuster Macmillan, pp 634-664.

Pomorina, I. (2000). Problem based learning in economics higher education. Learning and Teaching Support Network (LTSN) Centre for Economics. [viewed 21 Feb 2001] http:/ / econltsn.ilrt.bristol.ac.uk/advice/ pbl.htm [verified 28 Jan 2003 at http:/ / www.economics.ltsn.ac.uk/handbook/pbl/]

Poulter, M. (2000). Producing computer based presentations for the lecture theatre or the web. Learning and Teaching Support Network (LTSN) Centre for Economics. [viewed 17 Sep 2001, verified 28 Jan 2003] http: / / econltsn.ilrt.bris.ac.uk/advice/ preslect.htm

Rockman, S. (1999). President of Rockman et al, Educational Consulting Firm, San Francisco, USA.

Rogers, C. (1994). Experiential learning. Explorations in Learning \& Instruction: The Theory Into Practice (TIP) Database. [viewed 20 Nov 2001, verified 28 Jan 2003] http:/ / tip.psychology.org/ rogers.html

Salmon, G. (2001). Introducing E-tivities: The key to engaging students in online learning. Workshop 9 Presentation, Online Educa Berlin. Open University Business School, UK, 28 November. [viewed 29 Oct 2001, not found 28 Jan 2003] http:/ / www.online-educa.com/ workshops/09.htm

Schrum, L. (2000). Let's put pedagogy first: Technology as a tool to support instruction. Education World, The Educators Best Friend, Virtual Teachers Lounge. [viewed 5 Nov 2001, verified 28 Jan 2003] http: / / www.educationworld.com/a_tech/tech004.shtml

Shneiderman, B. (1994). Education by engagement and construction: Can distance learning be better than face-to-face? Institute for Systems Research, University of Maryland, 12 April. [viewed 29 Oct 2001, verified 28 Jan 2003] http: / / www.hitl.washington.edu/scivw / EVE/distance.html

Singh, S. \& Erwin, G. (2001). The rush to the web. Paper presented at the 3rd Annual Conference on World Wide Web Applications, Rand Afrikaans University, South Africa, 5-7 September.

Slay, J. (1997). The use of the Internet in creating an effective learning environment. Proceedings of the Third Australian World Wide Web Conference, 5-9 July, Southern Cross University, Australia. [verified 28 Jan 2003]

http: / / ausweb.scu.edu.au/aw97/ papers/slay/index.htm

Summary, R. \& Summary, L. (1998). The effectiveness of the World Wide Web as an instructional tool. Southeast Missouri State University, Cape Girardeau. [viewed 30 Nov 2001] http:/ / www.mtsu.edu/ edu/ proceed98/rsummary.html [verified 28 Jan 2003 at http:/ / www.mtsu.edu/ itconf/proceed98/rsummary.html] 
Tan, J. \& Wong, S. (1996). The Internet as a learning tool: Planning perspectives (The Singapore experience). Proceedings of the Internet Society's INET96 Conference, Transforming Our Society Now, Montreal, Canada, 24-28 June. [verified 28 Jan 2003] http: / / www.isoc.org/inet96/proceedings/c6/c6_3.htm

Taylor, J. C. (2002). Teaching and Learning Online: The Workers, the Lurkers and the Shirkers. University of Southern Queensland, Australia.

Valdez, G., McNabb, M., Foertsch, M., Anderson, M., Hawkes, M. \& Raack, L. (2000). Computer-based technology and learning: Evolving uses and expectations. North Central Regional Educational Laboratory (NCREL). [viewed 8 Nov 2001, verified 28 Jan 2003] http:/ / www.ncrel.org/tplan/ cbtl/toc.htm

Warters, B. (2000). Using WebQuests to promote integrative thinking in conflict studies. Conflict Management in Higher Education Report, 1(4) Nov/Dec 2000. Latest update 30 October 2001. [viewed 28 Nov 2001] http: / / www.campusadr.org/webquest/index.html [verified 28 Jan 2003 at http: / / www.campusadr.org/CMHER/ReportArticles /Edition1_4/CSWebQuest1_4a.html]

Watkins, C., Carnell, E., Lodge, C. \& Whalley, C. (1996). Effective learning. The School Improvement Network, Research Matters, No. 5. Institute of Education, University of London.

WebCT.com (2001). [viewed 29 Nov 2001] http: / / www.webct.com/

Web-Based Education Commission (2000). The power of the Internet for learning. [viewed 20 Oct 2001, verified 28 Jan 2003] http: / / www.ed.gov/offices / AC/WBEC/FinalReport/

Wilson, B. \& Lowry, M. (2000). Constructivist learning on the web. [viewed 29 Oct 2001, verified 28 Jan 2003] http:/ / ceo.cudenver.edu/ brent_wilson/WebLearning.html

Wood, D. G. (2001). WebQuests: Pathways for teaching to learn, learning to teach. The Technology Source, Nov / Dec, pp 1-6. Michigan Virtual University. [viewed 28 Nov 2001, verified 28 Jan 2003] http:// ts.mivu.org/default.asp?show=article\&id=910

Yang, G. (2001). The Second Annual Iowa State University WebCT User Survey. Iowa State University. [viewed 3 Dec 2001, verified 28 Jan 2003]. http:/ / www.public.iastate.edu/ gmyang/html/webct_suvey01.html

An earlier version of this paper was presented at the 20th International Conference on Technology and Education (ICTE) AFRICA, Potchefstroom University for CHE, South Africa, 2-5 April 2002.

Maylene Y Damoense, Lecturer

School of Business and Economics

Monash University South Africa Campus

Private Bag X60, Roodepoort, South Africa 1725

Tel +27 11950 4026, Fax +27 119504022

Email: maylene.damoense@buseco.monash.edu 